\title{
ISOLASI DAN UJI POTENSI BAKTERI DIAZOTROF NON SIMBIOTIK ASAL TANAH KEBUN KELAPA SAWIT DENGAN APLIKASI TANDAN KOSONG DAN LIMBAH CAIR PABRIK KELAPA SAWIT
}

\author{
(Isolation and Potential Test Of Non Symbiotic Diazotrophic Bacteria from Oil Palm Plantations' Soil \\ Fertilized by Empty Fruit Bunch and Palm Oil Mill Effluent)
}

HURYATUL ISLAM ${ }^{1)}$, NELVIA NELVIA ${ }^{2)}$, DELITA ZUL ${ }^{3)}$

${ }^{1}$ Program Studi IImu Pertanian Pascasarjana Universitas Riau, Pekanbaru, 28293, Indonesia

${ }^{2}$ Departemen Pertanian Fakultas Pertanian Universitas Riau, Pekanbaru, 28293, Indonesia

${ }^{3}$ Departemen Biologi Fakultas MIPA, Universitas Riau Pekanbaru, Indonesia

Email: huryatul09@gmail.com

\begin{abstract}
This study aimed was to isolate non-symbiotic diazotrophic bacteria from oil palm plantations fertilized with empty fruit bunch (EFB) and palm oil mill effluent (POME) and to analyze their potency. The soil samples were taken by purposive sampling method from 4 different treatments are mixed application $(E F B+P O M E), E F B$ application, POME application and without application (C), and each location was taken 3 times. Isolation of non-symbiotic diazotrophic bacteria was perfomed by using NFb and Ashby's media. The parameters observed were bacterial cells number, number of isolates and their potency. The cells number of non-symbiotic diazotrophic bacteria at the application sites Mixed> POME application $>E F B$ application> C. A total of 18 isolates were isolated and potentially as a diazotrophic bacteria, characterized by the ability of isolates to change the color of the NFb medium from green to blue and form pellicle. The highest potential isolates are NFBC232, NFBK21, and NFBC33.
\end{abstract}

Keywords : non symbiotic diazotrophic bacteria, empty fruit bunch, palm oil mill effluent

\section{PENDAHULUAN}

Nitrogen merupakan salah satu unsur yang melimpah di alam dalam bentuk N2 udara. Gas nitrogen (N2) tidak dapat langsung dimanfaatkan oleh tanaman. Nitrogen harus difiksasi oleh mikroba diazotrof, sehingga menjadi tersedia bagi tanaman. Kelompok bakteri diazotrof berdasarkan cara penambatannya dibagi menjadi dua yaitu bakteri simbiotik dan non simbiotik. Bakteri diazotrof non simbiotik adalah bakteri yang mampu mengubah molekul nitrogen menjadi amonium tanpa bergantung pada organisme lain (Danapriatna, 2010).

Penambatan nitrogen oleh bakteri diazotrof non simbiotik dipengaruhi oleh adanya bahan organik yang tersedia di dalam tanah (Handayanto dan Hairiah, 2007). Bahan organik merupakan sumber energi dan karbon bagi mikroorganisme yang hidup di dalam tanah. Ketersediaan bahan organik berkorelasi positif dengan jumlah populasi mikroorganisme tanah dengan ketersediaan energi bagi mikroorganisme tersebut.
Pemberian bahan organik secara berulang-ulang dan terus menerus akan meningkatkan jumlah, aktivitas dan populasi mikroorganisme tanah, terutama berkaitan dengan aktivitas dekomposisi dan mineralisasi. Sumber bahan organik yang digunakan pada perkebunan kelapa sawit adalah limbah kelapa sawit berupa tandan kosong kelapa sawit (TKKS) dan limbah cair pabrik kelapa sawit (LCPKS). Limbah kelapa sawit dapat dimanfaatkan sebagai sumber pupuk organik yang memiliki kandungan unsur hara yang dibutuhkan tanah dan tanaman, yaitu unsur hara N, P, K dan Mg. Winarti dan Neneng (2013) mengatakan bahwa perlakuan kombinasi limbah serat kelapa sawit memperlihatkan terjadinya peningkatan populasi mikroorganisme tanah rata-rata $53 \%$ dibandingkan kontrol,selanjutnya Widhiastuti et al (2006) menyimpulkan bahwa pemanfaatan limbah cair pabrik kelapa sawit sebagai pupuk dapat meningkatkan jumlah total bakteri tanah.

Beberapa jenis bakteri diazotrof non simbiotik seperti Beijerinckia, Derxia, Mycobacterium dan Azomonas. Hasil penelitian Widiastuti et al., (2010) 
menunjukkan bahwa bakteri Azotobacter sp. dapat dijumpai di perkebunan kelapa sawit, jambu mete, karet dan pertanian rakyat. Bakteri Azotobacter sp. dan Azospirillum sp. diketahui mampu menyumbang kebutuhan $\mathrm{N}$ tanaman antara 10 - $46 \mathrm{~kg}$ ha-1 (Simanungkit et al., 2006). Keberadaan bakteri diazotrof non simbiotik diharapkan dapat dijadikan salah satu alternatif untuk mengurangi penggunaan pupuk kimia. Tujuan penelitian ini adalah mendapatkan isolat bakteri diazotrof non simbiotik asal tanah kebun kelapa sawit yang sudah diaplikasi limbah kelapa sawit dan mengetahui potensinya.

\section{BAHAN DAN METODE}

Penelitian dilaksanakan pada bulan Agustus sampai Desember 2016. Sampel tanah diambil dari perkebunan kelapa sawit Kabupaten Pelalawan, Riau. Sampel tanah diambil dengan metode purposive sampling yaitu pada lahan yang telah diaplikasi tandan kosong kelapa sawit (TKKS), limbah cair pabrik kelapa sawit (LCPKS), campuran (TKKS+LCPKS) dan kebun masyarakat sebagai kontrol. Setiap lokasi diambil masingmasing 3 titik sebagai ulangan. Penelitian dilaksanakan di laboratorium Mikrobiologi FMIPA Universitas Riau. Medium yang digunakan adalah medium NFb dan Ashby's. Bahan yang digunakan pada medium NFB yaitu: $3,58 \mathrm{~g} \mathrm{C}_{4} \mathrm{H}_{6} \mathrm{O}_{5} ; 0,4 \mathrm{~g} \mathrm{KH}_{2} \mathrm{PO}_{4} ; 0,2 \mathrm{~g}$ $\mathrm{MgSO}_{4} \cdot 7 \mathrm{H}_{2} \mathrm{O} ; \quad 0,1 \mathrm{~g} \mathrm{NaCl} ; 0,026 \mathrm{~g}$ $\mathrm{CaCl}_{2} .2 \mathrm{H}_{2} \mathrm{O} ; \quad 0,017 \quad \mathrm{gFeCl}{ }_{3} 6 \mathrm{H}_{2} \mathrm{O} ; 2 \mathrm{~g}$ $\mathrm{Na}_{2} \mathrm{MoO}_{4} .7 \mathrm{H}_{2} \mathrm{O} ; 0,025 \mathrm{~g}$ bromothymol blue dan $15 \mathrm{~g}$ agar (medium padat), 1,75 g agar (semi padat) dengan pH 7 (Raffi dan Charyulu, 2012). Bahan yang digunaka pada medium Ashby's yaitu: $10 \mathrm{~g}$ manitol; $0,1 \mathrm{~g} \mathrm{CaCl}_{2} \cdot 2 \mathrm{H}_{2} \mathrm{O}$; 0,9 g $\mathrm{K}_{2} \mathrm{HPO}_{4} ; 0,1 \quad \mathrm{~g} \quad \mathrm{KH}_{2} \mathrm{PO}_{4} ; 5 \mathrm{mg}$ $\mathrm{Na}_{2} \mathrm{MoO}_{4} .2 \mathrm{H}_{2} \mathrm{O} ; 0,1 \mathrm{~g} \mathrm{MgSO}_{4} .7 \mathrm{H}_{2} \mathrm{O} ; 0,01 \mathrm{~g}$ $\mathrm{FeSO}_{4} .7 \mathrm{H}_{2} \mathrm{O} ; 5 \mathrm{mg} \mathrm{CaCO}_{3} ; 15 \mathrm{~g}$ agar (medium padat) dan 1,75 gr agar (medium semi padat), akuades $1000 \mathrm{ml}$ dengan pH 7 (Kizilkaya, 2009). Semua bahan dilarutkan dalam $1000 \mathrm{ml}$ akuades.Medium dipanaskan hingga mendidih, kemudian medium disterilisasi menggunakan autoklaf dengan suhu $121^{\circ} \mathrm{C}$ selama 15-20 menit pada tekanan 15 psi (Raffi dan Charyulu, 2012).

Penghitungan total jumlah sel bakteri dilakukan dengan mengambil sampel tanah sebanyak $1 \mathrm{~g}$, kemudian dilarutkan dalam $9 \mathrm{ml}$ larutan $\mathrm{NaCl} 0.85 \%\left(10^{-1}\right)$ dan dihomogenkan. Kemudian dilakukan seri pengenceran $10^{-1}$ sampai $10^{-4}$ untuk dilakukan penghitungan jumlah sel bakteri dan diinkubasikan pada suhu kamar yaitu $28^{\circ} \mathrm{C}$ selama $2 \times 24$ jam, kemudian dihitung total jumlah sel bakteri yang tumbuh dengan metode Colony Forming Unit (Waluyo, 2010).Isolasi bakteri dilakukan dengan mengambil sampel tanah sebanyak 1 $\mathrm{g}$, kemudian dilarutkan dalam $9 \mathrm{ml}$ larutan $\mathrm{NaCl}$ 0.85\% $\left(10^{-1}\right)$ kemudian dihomogenkan dan dilakukan seri pengenceran $10^{-1}$ sampai $10^{-4}$. Bakteri yang memiliki karakteristik berbeda akan ditumbuhkan dengan metode streak kuadran pada medium NFb untuk mendapatkan kultur murni. Bakteri yang telah murni diinokulasikan pada agar miring dan diinkubasi pada suhu $4^{\circ} \mathrm{C}$ sehingga dapat digunakan pada tahap selanjutnya.Karakteristik morfologi koloni bakteri yang diamati adalah bentuk, permukaan, elevansi, tepi dan warna. Morfologi sel diamati adalah bentuk sel dan pewarnaan Gram.

Seleksi dan uji potensi isolat bakteri dilakukan dengan mengambil $1 \mathrm{ml}$ isolat berumur 18-20 jam diinokulasi pada $9 \mathrm{ml}$ medium semi padat NFb dan Ashby's, kemudian diinkubasi pada suhu ruang selama 72 jam. Pada akhir inkubasi di permukaan medium sekitar $0,5 \mathrm{~cm}$ terlihat pelikel sertater jadi perubahan warna hijau menjadi biru pada medium NFb (Baldani et al., 2014).

\section{HASIL DAN PEMBAHASAN}

Total jumlah sel bakteri diazotrof non simbiotik berkisar $3,62-9,45 \times 10^{5} \mathrm{cfu} / \mathrm{g}$ tanah. Total jumlah sel bakteri tertinggi diperoleh pada lokasi aplikasi campuran (TKKS+LCPKS) dan terendah pada kebun masyarakat. Hasil sidik ragam menunjukkan bahwa lokasi sampling mempengaruhitotal jumlah sel bakteri diazotrof non simbiotik. Hasil uji lanjut terhadap total populasi bakteri diazotrof non simbiotik menggunakan uji berganda Duncan pada taraf $5 \%$ di sajikan pada Tabel 1.

Tabel 1. Total Jumlah Sel Bakteri Diazotrof Non Simbiotik

\begin{tabular}{ccc}
\hline \multirow{2}{*}{ Applicatian } & \multicolumn{2}{c}{ Medium (CFU/G Soil) } \\
\cline { 2 - 3 } Without & NFb & Ashby's \\
application & $5,87 \times 10^{5} \mathrm{a}$ & $3,62 \times 10^{5} \mathrm{a}$ \\
EFB application & $7,65 \times$ & \\
POME application & $8,32 \times 10^{5} \mathrm{ab}$ & $5,80 \times 10^{5} \mathrm{a}$ \\
Mixed application & $8,87 \times 10^{5} \mathrm{~b}$ & $9,45 \times 10^{5} \mathrm{~b}$ \\
\hline & 8,80 \\
\hline
\end{tabular}

Angka pada kolom yang sama yang diikuti huruf kecil yang sama, berbeda tidak nyata menurut uji berganda Duncan $\alpha=5 \%$.

Tabel 1. menunjukkan bahwa pada lokasi aplikasi campuran (TKKS+LCPKS) dan aplikasi LCPKS mempengaruhi total jumlah sel bakteri yang ditumbuhkan pada medium NFb, 
namun lokasi aplikasi TKKS dengan lokasi KM tidak mempengaruhi jumlah sel bakteri tersebut. Pada medium Ashby's diperoleh pada lokasi aplikasi campuran dan aplikasi LCPKS berpengaruh nyata terhadap total populasi bakteri dibandingkan lokasi KM, namun lokasi aplikasi TKKS dan lokasi KM tidak mempengaruhi bakteri diazotrof non simbiotik. Jumlah sel bakteri diazotrof non simbiotik pada lokasi aplikasi campuran lebih tinggi dipengaruhi oleh ketersediaan nutrisi berupa bahan organik dari aplikasi tandan kosong kelapa sawit dan limbah cair pabrik kelapa sawit.

Perkebunan kelapa sawit asal sampel tanah, mengaplikasikan TKKS dan LCPKS ke lahan perkebunan satu kali dalam enam bulan sebagai pupuk organik untuk memenuhi kebutuhan unsur hara tanaman. Kandungan bahan organik yang tinggi dapat mempengaruhi secara langsung jumlah sel bakteri bakteri dalam tanah. Ketersediaan bahan organik di lokasi sampling berkorelasi positif dengan jumlah populasi bakteri diazotrof non simbiotik di dalam tanah. Pernyataan ini didukung oleh Novita (2013) bahwa makin tinggi kadar bahan organik dalam tanah maka jumlah sel mikroba juga semakin tinggi. Widhiastuti et al., (2006) dan Pohan, (2007) mengatakan bahwa aplikasi LCPKS sebagai pupuk dapat meningkatkan jumlah total sel bakteri tanah.Winarti dan Neneng (2013) mengatakan bahwa perlakuan kombinasi limbah serat sawit memperlihatkan terjadinya peningkatan jumlah sel mikroorganisme tanah rata-rata 53\% dibandingkan kontrol.

Lokasi kebun masyarakat tidak mempengaruhi peningkatan total jumlah sel bakteri diazotrof nonsimbiotik, dikarenakan pada lokasi ini tidak ada penambahan bahan organik baik berupa TKKS maupun LCPKS, hanya aplikasi pupuk kimia yaitu urea, TSP, $\mathrm{KCL}$, dolomit dengan takaran 1-1,5 kg/pokok. Novita (2013) mengatakan bahwa total jumlah sel mikroba dengan perlakuan pupuk organik lebih tinggi dibandingkan perlakuan pupuk organik yang dikombinasikan dengan NPK. Jumlah sel bakteri pada setiap tanah berbeda, hal ini karena beberapa faktor seperti $\mathrm{pH}$, kelembaban, kandungan unsur hara (Oliveira et al., 2004), suhu, aerasi, drainase yang baik, dan kandunganbahanorganik (Agustian et al., 2012).

Tabel 3. Karakteristik Morfologi Koloni dan Sel Isolat Bakteri Diazotrof Non Simbiotik.

\begin{tabular}{|c|c|c|c|c|c|c|c|c|}
\hline \multirow{2}{*}{ No } & \multirow{2}{*}{ Kode Isolat } & \multicolumn{5}{|c|}{ Morfologi Koloni } & \multirow{2}{*}{$\begin{array}{c}\text { Morfologi } \\
\text { Sel }\end{array}$} & \multirow[t]{2}{*}{ Gram } \\
\hline & & Bentuk & Permukaan & Elevasi & Tepi & Warna & & \\
\hline 1 & NFBTKKS121 & Bulat & $\begin{array}{l}\text { Halus } \\
\text { mengkilap }\end{array}$ & Cembung & Berombak & Bening & Bulat & - \\
\hline 2 & NFBLC32 & $\begin{array}{l}\text { Tidak } \\
\text { teratur }\end{array}$ & Kering & Cembung & Berombak & Bening & Batang & - \\
\hline 3 & NFBC134 & Bulat & Kering & Datar & Berombak & Bening & Batang & - \\
\hline 4 & NFBC211 & Bulat & $\begin{array}{l}\text { Halus } \\
\text { mengkilap }\end{array}$ & Cembung & Berombak & Bening & Bulat & - \\
\hline 5 & NFBC232 & Bulat & Halus & Tinggi & Berombak & Bening & Bulat & - \\
\hline 6 & NFBC31 & $\begin{array}{l}\text { Tidak } \\
\text { teratur }\end{array}$ & Halus & Datar & Berombak & Oranye & Batang & - \\
\hline 7 & NFBC32 & $\begin{array}{l}\text { Tidak } \\
\text { teratur }\end{array}$ & Halus & Tinggi & Rata & $\begin{array}{l}\text { Putih } \\
\text { keruh }\end{array}$ & Batang & + \\
\hline 8 & NFBC33 & $\begin{array}{l}\text { Tidak } \\
\text { teratur }\end{array}$ & Kering & Cembung & Berombak & Bening & Batang & - \\
\hline 9 & NFBK21 & $\begin{array}{l}\text { Tidak } \\
\text { teratur }\end{array}$ & Kering & Datar & Rata & Bening & Batang & - \\
\hline 10 & ASBTKKS224 & $\begin{array}{l}\text { Tidak } \\
\text { teratur }\end{array}$ & $\begin{array}{c}\text { Halus } \\
\text { mengkilap }\end{array}$ & Tinggi & Rata & Bening & Batang & - \\
\hline 11 & ASBLC133 & Bulat & Licin & Cembung & Rata & Bening & Batang & - \\
\hline 12 & ASBLC211 & Bulat & Halus & Cembung & Rata & Putih & Batang & - \\
\hline 13 & ASBLC32 & Bulat & Halus & Datar & Rata & Bening & Batang & - \\
\hline 14 & ASBLC35 & Bulat & Halus & Cembung & Berombak & $\begin{array}{l}\text { Merah } \\
\text { muda }\end{array}$ & Bulat & - \\
\hline 15 & ASBC224 & Bulat & Kering & Datar & Rata & $\begin{array}{l}\text { Putih } \\
\text { susu }\end{array}$ & Bulat & - \\
\hline 16 & ASBC24 & Bulat & $\begin{array}{l}\text { Halus } \\
\text { mengkilap }\end{array}$ & Tinggi & Berombak & Putih & Bulat & - \\
\hline 17 & ASBC313 & $\begin{array}{l}\text { Tidak } \\
\text { teratur }\end{array}$ & Halus licin & Cembung & Berombak & Putih & Batang & + \\
\hline 18 & ASBK14 & Bulat & Licin & Datar & Rata & Krem & Batang & - \\
\hline
\end{tabular}




\section{Karakteristik Isolat Bakteri Diazotrof Non Simbiotik}

Isolasi bakteri diazotrof non simbiotik dari empat lokasi sampling memiliki karakter morfologi koloni dan sel yang sangat bervariasi. Bentuk koloni dari isolat pada umunya bulat dan tidak teratur, elevasi bervariasi seperti cembung, datar dan tinggi dengan permukaan halus, halus mengkilap dan licin. Tepi koloni umumnya berombak dan rata, dengan warna koloni bervariasi seperti bening, putih keruh, putih susu, merah muda, oranye dan krem. Hasil karakteristik isolat bakteri diazotrof non simbiotik disajikan pada Tabel 3.

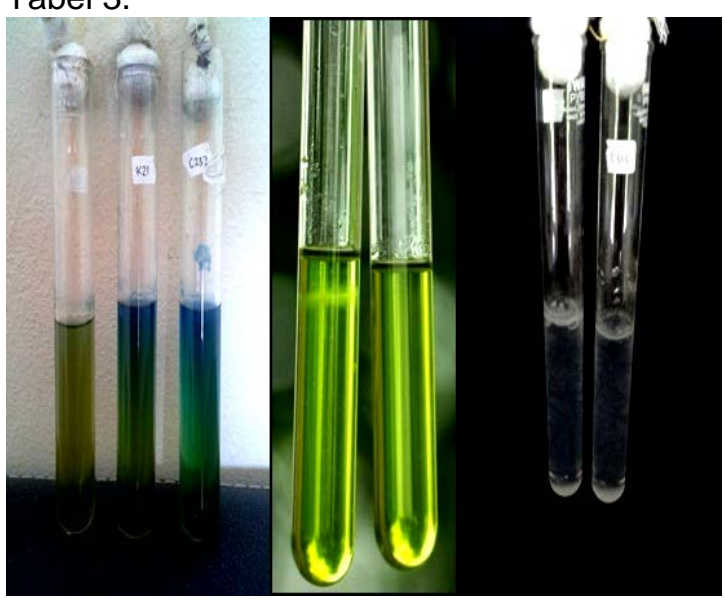

Gambar 1. Uji potensi isolat bakteri diazotrof non simbiotik pada medium NFb, (A) perubahan warna, (B) pembentukan pelikel dan pada medium Ashby's (C) pembentukan pelikel.

Hartono dan Junaidi (2014) melaporkan hal yang sama bahwa isolat bakteri penambat nitrogen non simbiotik memiliki bentuk koloni bulat dan tidak teratur, elevasi koloni sebagian besar rata dengan permukaan halus mengkilap, tepi koloni rata dan berombak dengan warna koloni transparan, putih transparan, putih, dan putih keruh. Akan tetapi Agustian et al., (2012) dan Wedastari (2002) memperoleh bakteri diazotrof non simbiotik umumnya berbentuk bulat dan cembung, warna umumnya putih susu dan bening. Tarigan et al., (2013) juga melaporkan karakteristik bakteri diazotrof non simbiotik bentuk koloni umumnya bulat dan tak beraturan, tepi koloni bervariasi seperti berombak, berbelah, utuh, dan keriting dengan elevasi paling dominan berbentuk rata, warna koloni putih kuning.

Hasil pewarnaan Gram yang diuji pada 18 isolat bakteri diazotrof non simbiotik menunjukkan bahwa 2 isolat bersifat Gram positif dan 16 isolat bersifat Gram negatif. Penelitian ini sejalan dengan Hartono dan Junaidi (2014), yang memperoleh isolat bakteri
Gram negatif yang lebih banyak dibandingkan dengan kelompok isolat bakteri Gram positif. Hal tersebut juga ditemukan oleh Firrani (2011).

\section{Seleksi dan Potensi Isolat Bakteri}

Sebanyak 18 isolat berhasil diisolasi dari empat lokasi sampling, 9 isolat diperoleh dari medium NFb dan 9 isolat dari medium Ashby's. Jumlah isolat yang diperoleh tidak jauh berbeda dengan penelitian Firrani (2011), mendapatkan 20 isolat bakteri penambat nitrogen bebas yang diisolasi dari akar kelapa sawit. Silva et al., (2011), berhasil mengisolasi 22 isolat bakteri penambat $N$ non simbiotik berdasarkan keragaman fenotipik tertinggi dari sampel tanah yang berbeda yaitu hutan asli, hutan sekunder muda, hutan sekunder tua, agroforestri, pertanian dan padang rumput. Selanjutnya Hartono dan Junaidi (2014) mendapatkan 20 isolat bakteri penambat $\mathrm{N}$ non simbiotik pada tanah pertanaman jagung dan padi. Jolly et al., (2010) memperoleh 10 isolat Azospirillum dari rizosfer Colocasia esculenta berdasarkan kemampuannya dalam memfiksasi N. Hossain et al., (2015) berhasil mengisolasi 20 bakteri strain Azospirillum spp dari rizosfer, non rizosfer dan akar tanaman padi di Bengal utara.

Tabel 2. Potensi Berbagai Isolat Bakteri Diazotrof Non Simbiotik

\begin{tabular}{lcc}
\hline Kode isolat & $\begin{array}{c}\text { Pembentukan } \\
\text { pelikel }\end{array}$ & $\begin{array}{c}\text { Perubahan } \\
\text { warna medium }\end{array}$ \\
\hline NFBTKKS121 & $\checkmark$ & + \\
NFBLC32 & $\checkmark$ & + \\
NFBC134 & $\checkmark$ & + \\
NFBC211 & $\checkmark$ & + \\
NFBC232 & $\checkmark$ & ++ \\
NFBC31 & $\checkmark$ & + \\
NFBC32 & $\checkmark$ & + \\
NFBC33 & $\checkmark$ & ++ \\
NFBK21 & $\checkmark$ & ++ \\
ASBTKKS24 & $\checkmark$ & - \\
ASBLC133 & $\checkmark$ & - \\
ASBLC211 & $\checkmark$ & - \\
ASBLC32 & $\checkmark$ & - \\
ASBLC35 & $\checkmark$ & - \\
ASBC24 & $\checkmark$ & - \\
ASBC224 & $\checkmark$ & - \\
ASBC313 & $\checkmark$ & - \\
ASBK14 & $\checkmark$ & - \\
\hline
\end{tabular}

Keterangan: terbentuk pelikel $(\sqrt{ })$, biru (+), biru tua $(++)$, tidak ada perubahan $(-)$, isolat pada medium NFb (NFB), isolat pada medium Ashby's (ASB), tandan kosong kelapa sawit (TKKS), limbah cair (LC), campuran (C), kebun masyarakat $(\mathrm{K})$. 
Semua isolat yang diperoleh merupakan bakteri diazotrof non simbiotik ditandai dengan kemampuan isolat membentuk pelikel dan perubahan warna medium NFb dari warna hijau menjadi biru. Hasil uji potensi fiksasi $\mathrm{N}$ pada 18 isolat, disajikan pada Gambar 1 dan Tabel 2.

Gambar 1 dan Tabel 2 menunjukkan bahwa sebanyak 9 isolat terjadi perubahan warna medium NFb dari hijau menjadi biru dan biru tua serta 18 isolat terbentuk pelikel pada medium NFb dan Ashby's. Semua isolat berpotensi dalam memfiksasi $\mathrm{N}$, namun hanya 3 isolat yang memiliki potensi tertinggi yaitu NFBC232, NFBC33 NFBK21. Hasil penelitian Karina (2016), Isti'anah (2014) dan Metasari (2011) memperoleh bakteri diazotrof non simbiotik ditandai dengan terbentuknya pelikel berupa serabut atau cincin berwarna putih dipermukaan dan terjadi perubahan warna medium NFb dari hijau menjadi biru.

Menurut Baldani et al., (2014) bahwa ciri-ciri bakteri diazotrof non simbiotik dapat merubah medium NFb dari hijau menjadi biru dan terbentuknya pelikel. Harran dan Ansori (1992), Caceres (1982 dalam Nurosid et al., 2008) mengatakan bahwa perubahan warna medium NFb terjadi karena sifat indikator bromthymol blue yang berubah hijau menjadi biru pada $\mathrm{pH}$ yang lebih tinggi, sebagai akibat adanya aktivitas nitrogenase, karena medium $\mathrm{NFb}$ mampu menyediakan nutrisi yang dibutuhkan oleh bakteri penambat nitrogen non simbiotik.Adanya pembentukan pelikel menjadi ciri pertumbuhan bakteri diazotrof non simbiotik sebagai indikator bahwa bakteri tersebut mampu mereduksi sumber $\mathrm{N}$ dari media sebagai aktivitasdari nitrogenase (Schlegel, 1994). Hal ini membuktikan bahwa tanah asal perkebunan kelapa sawit yang diaplikasi tandan kosong dan limbah cair pabrik kelapa sawit memiliki potensi sebagai sumber isolat bakteri diazotrof non simbiotik

\section{KESIMPULAN DAN SARAN}

Total jumlah sel bakteri diazotrof non simbiotik pada lokasi aplikasi campuran (TKKS+LCPKS) > aplikasi LCPKS > aplikasi TKKS > lokasi KM. Karakteristik morfologi memiliki bentuk koloni bulat dan tidak teratur, permukaan dominan halus, elevasi cembung, datar dan tinggi, dengan tepi berombak dan rata. Warna koloni putih, putih susu, bening, oranye dan merah muda. Bentuk sel bulat dan batang serta 16 isolat bersifat Gram negatif dan 2 isolat bersifat Gram positif.Sebanyak 18 isolat berhasil diisolasi dan berpotensi sebagai bakteri penambat nitrogen. Isolat yang memiliki potensi tertinggi adalah NFBC232, NFBK21, dan NFBC33.

\section{DAFTAR PUSTAKA}

Agustian, Syafei R., Maria, L. 2012.Keragaman Bakteri Penambat $\mathrm{N}$ Pada Rhizosfer Titonia (Titoniadiversifolia) yang Tumbuh Pada Tanah Masam Ultisol. Jurnal Solum.Vol. 9 No.2: 98-105.

Baldani, JL., Reis,VM.,Videira, SS., Boddey, LH., Baldani, VLD. 2014. The Art of Isolating Nitrogen Fixing Bacteria from Non-Leguminous Plant using $\mathrm{N}$ Free Semi Solid Media: a Particular Guide for Microbiologists.Plant Soil DOI 10.1007/s11104-014-218-6.

Bishnu, Saha, T., Mazumdar, D., Chakrabarti, K., Chakraborty, A. 2008.Assasement of the Impact of Pesticide Residues on Microbiological and Biochemical Parameters of Tea Garden Soils in India, Journal of Enviromental Science and Healt. 43 (8):723-731.

Danapriatna, N. 2010.BiokimiaPenambatan Nitrogen olehBakteri Non Simbiotik. Jurnal Agribisnis dan Pengembangan Wilayah.Vol.1 No.2.

Firrani, M. 2011. Isolasi dan Uji Kemampuan Bakteri Endofit Diazotrof yang Memfiksasi Nitrogen Bebas pada Akar Kelapa Sawit (Elaeis guineensis Jaqc.). Departemen Biologi Fakultas Matematika dan IImu Pengetahuan Alam.Universitas Sumatera Utara. Medan.

Hartono dan Jumadi, O. 2014. Seleksi dan Karakterisasi Bakteri Penambat Nitrogen Non Simbiotik Pengekskresi Amonium Pada Tanah Pertanaman Jagung (Zea mays L.) dan Padi (Oryza sativa L.) Asal Kabupaten Barru Sulawesi Selatan Indonesia. Jurnal Sainsmat. Vol.3. No.2:143-153.

Handayanto, E.,Hairiah K. 2007. Biologi Tanah: Landasan Pengelolaan Tanah Sehat. Pustaka Adipura. Yogyakarta.

Harran, S., Ansori N. 1992. Bioteknologi Pertanian Bogor: Pusat Antar Universitas Bioteknologi Institut Pertanian Bogor.

Jolly,SN.,Shanta, NA., Zahed, UMK. 2010. Quantification of Heterotrophic Bacteria and Azospirillum from the Rhizosphere of Taro (Colocasiaesculenta L. Schoot.) and the Nitrogen Fixing Potensial of Isolated Azospirillum.International Journal of Botany 6(2):117-121. 
Karina, A I. 2016. Isolasi dan Identifikasi Bakteri Penambat Nitrogen, Pelarut Fosfat, dan Bakteri Pendegradasi Selulosa pada Tanah Bekas Tanaman Bawang (Allium cepa L.) yang diberi Biofertilizer. Fakultas Sains dan Teknologi.Universitas Airlangga.

Kizilkaya, R. 2009. Nitrogen Fixation Capacity of Azotobacter spp. Strains Isolated from Soils in Different Ecosystems and Relationship Between them and the Microbiological Properties of Soils.Journal of Enviromental Biology.30(1):73-82.

Lay, L.B.W. 1994. Analisis Mikroorganisme di Laboratorium. PT Raja Grapindo Persada, Jakarta.

Metasari, K. 2011. Eksplorasi Bakteri Penambat Nitrogen Non Simbiotik dari Tanah Kawasan Mangrove Wonorejo Surabaya.Universitas Airlangga.

Novita D. 2013. Pengaruh Pupuk Terhadap Sifat Kimia Tanah dan Populasi Mikrob Rizosfer Tanaman Kilemo (Litsea cubeba Pers). Departemen IImu Tanah dan Sumberdaya Lahan Fakultas Pertanian Bogor. IPB. Bogor.

Oliveira,ALM.,Canuto, EL., Silva, EE., Reis, VM., Baldani, Jl. 2014. Survival of Endophytic Diazotrophic Bacteria in Soil Under Different Moisture Levels. Journal Brazilian Microbiology 35:295-299.

Raffi, MMD., Charyulu, PBBN. 2012. Nitrogen Fixation by the Native Azotospirillum spp. Isolate from Rhizosphere and NonRhizosphere of Foxtail Millet.Asian Journal Biological and Life Science. 1:213-218.
Schlegel, HG. 1994.Mikrobiologi Umum. Ed ke-6. Terjemahan dari Microbiology 6st editing, oleh R.M Tedjo Baskoro. 1984. Yogyakarta: Gadjah Mada. University Press.

Silva, KD., Rafaela,SAN., Adriana, SL., Alexandra, B., Fatima, MDSM. 2011.Density and Diversity of Diazotrophic Bacteria Isolated from Amazonian Soils using N-Free SemiSolid Media.Science Agriculture.68(5):518-525.

Susilowati, DN., Saraswati, R., Hastuti, RD., Yuniarti, E. 2007. Peningkatan Serapan $\mathrm{N}$ pada Kedelai yang Diinokulasi Bakteri Diazotrof Endofit di Medium Vermiculit. Jurnal Tanah Iklim, 26:41-46.

Tarigan,RS., Jamilah, I., Elimasni. 2013. Seleksi Bakteri Penambat Nitrogen dan Penghasil Hormon IAA (Indole Acetic Acid) dari Rizosfer Tanah Perkebunan Kedelai (Glycine max L.). Sin Biology. Vol. 1 (2):42-48.

Waluyo, L. 2010. Teknik dan Metode Dasar Dalam Mikrobiologi. Universitas Muhammadiyah. Malang.

Widhiastuti, R., Suryanto, D., Muklis., Wahyuningsih, H. 2006. Pengaruh Pemanfaatan Limbah Cair Pabrik Pengolahan Kelapa Sawit Sebagai Pupuk terhadap Biodiversitas Tanah. Jurnal IImiah Pertanian Kultura. Vol. 41. NO 1.

Winarti, S and Neneng, L. 2013. Pengaruh Pemberian Limbah Kelapa Sawit Terhadap Sifat Fisika, Kimia dan Biologi Tanah pada Lahan Kritis Eks Penambangan Emas. Jurnal Agripeat.Vol. 14. NO 2 
Jurnal Agroteknologi, Vol. 9 No. 2, Februari 2019 : 35 - 40 